\title{
Worldwide excellence in evidence
}

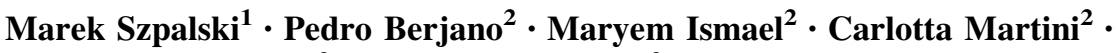 \\ Riccardo Cecchinato $^{2}$. Claudio Lamartina ${ }^{2}$
}

Published online: 10 November 2016

(c) Springer-Verlag Berlin Heidelberg 2016

For the second year in a row European Spine Journal is the journal with the highest proportion of articles born from international collaboration amongst the clinical orthopaedic and spine journals, both in 2014 and 2015 with 20.12 and $19.35 \%$ of the articles, respectively (Fig. 1).

This places European Spine Journal ahead of other clinical orthopaedic journals of great renown and consolidated scientific value such as the Journal of Bone and Joint Surgery (Am), the Bone and Joint Journal (formerly JBJS$\mathrm{Br}$ ), International Orthopaedics, Clinical Orthopaedics and Related Research as well as the other top spine journals.

It is a fact that European Spine Journal has a worldwide attraction for authors wishing to publish in a distinguished global journal. Even if European is the first word in the name of European Spine Journal, the journal wants to embrace authors from all over the world, extending collaboration to international experts within their competences (Fig. 2).

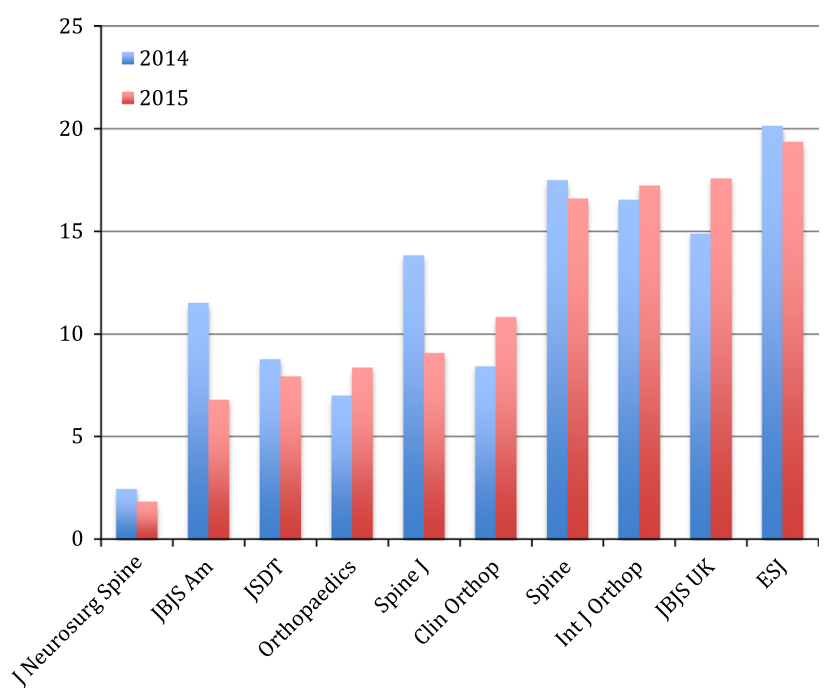

Fig. 1 Percentage of publications from international collaborations in the last 2 years
Marek Szpalski

mszp@skynet.be

1 Department of Orthopedic Surgery, Iris South Hospitals, 1180 Brussels, Belgium

2 GSpine4, IRCCS Istituto Ortopedico Galeazzi, Milan, Italy 
Fig. 2 European Spine

Journal's reviewers by country

\author{
- UNITED STATES \\ - UNITED KINGDOM \\ - GERMANY \\ - SWITZERLAND \\ CHINA \\ - CANADA \\ - ITALY \\ - JAPAN \\ AUSTRALIA \\ NETHERLANDS \\ SPAIN \\ BELGIUM \\ FRANCE \\ - KOREA \\ SWEDEN \\ TURKEY \\ GREECE \\ $\square$ AUSTRIA \\ HONG KONG \\ INDIA \\ - DENMARK \\ FINLAND \\ ISRAEL \\ IRAN \\ IRELAND \\ NEW ZEALAND \\ - NORWAY \\ PORTUGAL \\ - BRAZIL \\ CZECH REPUBLIC \\ TAIWAN \\ RUSSIAN FEDERATION \\ SINGAPORE \\ ARGENTINA \\ CHILE \\ CROATIA \\ EGYPT \\ OMAN \\ POLAND \\ SAUDI ARABIA \\ ANTIGUA AND BARBUDA \\ COLOMBIA \\ HUNGARY \\ NIGERIA \\ SLOVENIA \\ SOUTH AFRICA \\ THAILAND \\ UNITED ARAB EMIRATES
}

Thus, the journal places a bridge to share knowledge with increased quality of the papers given to our readership. With these aims, we encourage authors to send us large multicentric trials, prospective studies, international groups papers; European Spine Journal, while born in Europe, aims to be the home of worldwide spine experts.

\section{Compliance with ethical standards}

Conflict of interest No authors of this paper has any conflict of interest regarding the treated subject. 